\title{
Rancang Bangun Dashboard Smart System Manajemen RT/RW untuk Mendukung Society 5.0
}

\author{
Muhammad Sony Maulana ${ }^{\mathrm{a} 1}$, Raja Sabaruddin ${ }^{\mathrm{a} 2}$, Nurmalasaria ${ }^{\mathrm{a}}$ \\ a Program Studi Sistem Informasi Kampus Kota Pontianak, Universitas Bina Sarana Informatika \\ Jl. Abdurahman Saleh No.18 \\ ${ }^{1}$ muhammad.sony.momebsi.ac.id \\ ${ }^{2} r a j a \cdot r j d e b s i \cdot a c \cdot i d$ \\ ${ }^{3}$ nurmalasari.nrr@bsi.ac.id
}

\begin{abstract}
Abstrak
Pemanfaatan teknologi tepat guna diterapkan pada lingkungan RT(Rukun Tetangga)-RW (Rukun Warga) akan meningkatkan kualitas peran dan fungsi RT/RW, apalagi RT/RW merupakan garda terdepan yang dapat mendukung pembangunan nasional. Dengan konsep layanan berbasis teknologi, RT/RW akan lebih dekat dengan warga terutama di masa pandemi covid 19 yang membatasi pertemuan tatap muka secara langsung. Dengan adanya peningkatan ini tentunya mendukung perkembangan masyarakat Indonesia ke arah society 5.0. Tujuan dari penelitian ini adalah tahapan membangun dashboard aplikasi sistem pintar manajemen RT/RW berbasis online yang dapat menfasilitasi laporaan warga terhadap kondisi lingkungan sekitar RT/RW, berupa kerusakan fasilitas atau kondisi sosial di sekitar lingkungan RT/RW dan menjalankan fungsi administratif RT/RW secara digital. Metode pengembangan Aplikasi ini dengan metode SDLC (Software Development Life Cycle) dengan tahapan analisa kebutuhan data, perancangan dan desain perangkat lunak, pembuatan aplikasi (programming) dan uji coba aplikasi sebelum diimplementasikan kepada RT-RW. Hasil yang didapat berupa aplikasi dashboard yang bisa membantu fungsi dan peran RT/RW baik secara manajemen administratif, maupun penyebaran informasi dalam bentuk berita kegiatan seputar RT/RW. Kesimpulan bahwa API dari dashboard aplikasi ini dapat dikembangkan untuk membangun aplikasi mobile.
\end{abstract}

Kata kunci: Dashboard, API, Mobile, RT-RW, SDLC, Society 5.0

\section{Design and Build a Smart RT-RW Management System Dashboard to Support Society 5.0}

\begin{abstract}
The use of appropriate technology applied to the RT (Rukun Tetangga) -RW (Rukun Warga) environment will improve the quality of the roles and functions of the RT/RW, especially since RT-RW is the front guard that can support national development. With the concept of technology-based services, RT-RW will be closer to residents, especially during the Covid 19 pandemic which limits face-to-face meetings. With this increase, it certainly supports the development of Indonesian society towards society 5.0. The purpose of this research is to build a dashboard application for an online-based RT/RW smart management system that can facilitate citizen reports on environmental conditions around the RT/RW, in the form of damage to facilities or social conditions around the RT/RW environment and carry out RT/RW administrative functions digital. This application development method uses the SDLC (Software Development Life Cycle) method with the stages of analyzing data requirements, designing and designing software, making applications (programming) and testing applications before being implemented in RT/RW. The results obtained are in the form of a dashboard application that can help the RT/RW function and role both administratively as well as disseminating information in the form of news about RT/RW activities. The conclusion is that the API from the application dashboard can be developed to build mobile applications.
\end{abstract}

Keywords: Dashboard, API, Mobile, RT-RW, SDLC, Society 5.0 


\section{Pendahuluan}

Indonesia memasuki era society 5.0 yang merupakan tatanan masyarakat yang berpusat pada manusia (humancentered) dan berbasis teknologi (technology based). Sebagai catatan, era society 5.0 didahului dengan era berburu (society 1.0), pertanian (society 2.0), industry (society 3.0), dan teknologi informasi (society 4.0)[1].

Rukun Tetangga (RT) dan Rukun Warga (RW) merupakan gambaran siklus sistem pemerintahan presidensial terkecil yang ada dalam lingkungan masyarakat kita (Indonesia). RT/RW merupakan salah satu komponen utama dalam konsep community-centered local government [2]. RT memiliki tugas menjadi perpanjangan tangan pemerintah daerah seperti membantu menjalankan tugas pelayanan kepada masyarakat, menyerap aspirasi masyarakat, membantu pendataan kependudukan dan administrasi pemerintah, membantu terciptanya ketentraman, ketertiban dan kerukunan antar warga serta menggerakan swadaya masyarakat melalui gotong royong dan pemebrdayaan masyarakat guna menciptakan lingkungan yang aman, bersih tertib dan lestari[3].

Sebagai bentuk pemerintahan terkecil RT/RW melakukan berbagai fungsi tersebut diatas seperti pelayanan administratif dalam bentuk surat pengantar, RT-RW. Mengumpulkan aspirasi masyarakat dalam bentuk laporan yang kemudian disampaikan langsung kepada lurah untuk ditindaklanjuti. Mendukung kegiatanan-kegiatan baik yang dihimbau olah lurah ataupun inisiatif warga terkait swadaya masyarakat dalam menjaga kebersihan dan kelestarian lingkungan hidup. Selain RT, RW dan partisipasi masyarakat juga sangat berperan dalam keberhasilan usulan dana proyek pembangunan berbasis pada kebutuhan nyata[4].

Setiap warga pastinya mengharapkan pelayanan surat pengantar RT/RW secara cepat dan tepat. Namun, tidak semua harapan tidak dapat terwudud dengan baik[5]. Hal ini disebabkan selain menjadi RT/RW biasanya ketua RT/RW berprofesi sebagai pekerja kantor/swasta. Sehingga untuk pelayanan surat menyurat butuh waktu beberapa hari, Hal ini bukan bearti RT/RW tersebut tidak kompeten, tetapi justru pengurus RT/RW ini membutuhkan suplemen untuk mempermudah mereka dalam memberikan layanan.

Memasuki era keterbukaan informasi ini perlu untuk mendukung kinerja RT-RW yang berbasis teknologi informasi, apalagi saat ini Indonesia sedang dihadapi pandemi covid 19 sejak diumumkan pada pertengahan bulan Maret 2020 hingga saat ini. Pembatasan mobilitas (social distancing) melalui tatap muka demi mencegah penyebaran covid 19 [6], menjadi suatu kendala sendiri untuk berinteraksi antar warga maupun warga dan RT.

Maka dari itu perlu adanya pengembangan sebuah aplikasi yang dapat mendukung kinerja RT-RW sebagai bagian dari pemerintahan terkecil. Tujuannya adalah agar aplikasi yang dikembangkan dapat berguna bagi masyarakat terutama dalam manajemen RT-RW, dan menjadi dasar bahan penelitian selanjutnya dalam mengembangkan aplikasi-aplikasi untuk menunjang society 5.0 dan Smart City. Dengan mengembangkan sebuah sistem informasi warga berbasis RT maka semua kebutuhan yang berhubungan dengan warga dapat diakomodir secara online, terutama dalam hal paling mendasar yaitu pengelolaan data warga[7].

Manfaat dari penelitian ini adalah: (1) menghasilkan sebuah dashboard aplikasi Smart Sistem Manajemen RT/RW (SIMART) yang dapat mendukung kinerja RT/RW, (2) mempermudah warga untuk berkomunikasi dengan RT-RW dan mendapatkan layanan surat pengantar dari RT/RW tanpa harus bertatap muka terlebih dahulu. Urgensi atau keutamaan dalam penelitian ini adalah: (1) Dapat mendukung program pemerintah dalam mengembangkan Smart City dan mendukung Indonesia dalam menghadapi society 5.0. (2) Memudahkan RT-RW dalam melakukan manajemen administratif dan publikasi kegiatan-kegiatan serta penanganan laporan-laporan warga. (3) Dapat meningkatkan kualitas layanan RT terhadap warga dan mendukung proses society 5.0, karna semua informasi didapatkan dalam genggaman tangan, dan mudah dipantau oleh RW dan Kepala Desa/Lurah.

\section{METODOLOGI}

\section{A. Metode Penelitian}

Metode yang digunakan adalah metode kualitatif yaitu menerapkan perancangan sistem melalui tahap-tahap Siklus Hidup Pengembangan Sistem (System Development Life Cycle-SDLC) dengan metode waterfall[8]. Tahap-tahapan tersebut adalah sebagai berikut:

1) Tahapan analisa kebutuhan objek penelitian: Pada tahapan ini anggota peneliti satu dan anggota peneliti dua melakukan survei untuk mengumpulkan data serta melakukan wawancara dengan responden yaitu Ketua RT. 004/RW.008 Keluarahan Parit Mayor dan Ketua RW.005 Keluarahan Kotabaru mengenai prosedur manajemen RTRW, seperti prosedur laporan kegiatan warga, tata cara laporan aspirasi warga, iuran warga, laporan penggunaan iuran warga, dan pelayanan surat-menyurat pada RT-RW, di Kelurahan Pontianak Timur dan Kotabaru. Setelah data terkumpul maka data tersebut dianalisa dan disampaikan kepada ketua peneliti. Survey dilakukan sebelum pandemi covid 19.

2) Tahapan perancangan sistem atau desain: Ketua peneliti kemudian melakukan perancangan sistem dilakukan berdasarkan hasil tahap Analisa kebutuhan objek penelitian oleh anggota peneliti satu dan anggota peneliti dua. Tahap ini menentukan kebutuhan (requirement) yang dimungkinkan ada di dalam aplikasi SIMART. Wujud dari proses analisa diantaranya berbentuk sebuah sistem dokumentasi yang digunakan untuk merancang UML sistem, sebagai landasan pengembangan aplikasi. Unified Modelling Language (UML) adalah sebuah teknik pengembangan sistem yang menggunakan Bahasa grafis sebagai alat untuk pendokumentasian dan spesifikasi pada sistem[9].Pada tahap ini juga aplikasi SIMART disusun dengan pendekatan berorientasi objek. Selain itu juga dilakukan desain basis data sesuai kebutuhan aplikasi. 
3) Tahapan pembuatan kode program: Pada tahap ini dilakukan pengkodean berdasarkan kebutuhan seperti frontend dan backend dari penggunaan sistem SIMART. Pengkodean di lakukan oleh programmer dengan menggunakan framework YII sehingga mudah, cepat dan dari sisi keamanan sudah terjamin. Yii adalah framework (kerangka kerja) PHP berbasis-komponen, berkinerja tinggi untuk pengembangan aplikasi Web berskalabesar[10]

4) Tahapan uji coba dan evaluasi: Semua peneliti baik ketua maupun anggota melakukan pengujian metode black box testing, yaitu pengujian dengan melihat input, proses, output dan kesimpulan yang akan di hasilkan[11]. Hasilnya dituangkan dalam dokumen hasil penelitian dan terus melakukan evaluasi apabila ada ketidaksesuaian antara rancangan sistem dengan aplikasi yang dihasilkan.

\section{B. Analisa Kebutuhan Sistem}

Tahapan penelitian dalam pengembangan aplikasi SIMART di mulai dari kebutuhan analisis, desain, pembuatan kode, pengujian dan implementasi.

1) Kebutuhan analisis/Analisa: Proses kebutuhan Analisa pada SIMART yaitu siapa saja yang menjadi aktor atau pengguna di aplikasi SIMART. Adapun pengguna yang mengelola dan mengkases aplikasi SIMART adalah warga yang terdaftar di RT-RW tersebut, bendahara RT-RW, Ketua RT-RW dan Lurah. Data yang di butuhkan dalam pembuatan aplikasi ini adalah data pengajuan surat ke RT-RW oleh warga.

2) Desain: Analisis Desain atau Analisa kebutuhan software pada aplikasi SIMART menerangkan apa saja yang dapat dilakukan oeh aplikasi sehingga dapat memenuhi kebutuhan pengguna.

a) Kebutuhan pengguna

1. Warga

- Login

- Mengakses data berita

- Mengkases data infromasi

- Mengkases data iuran

- Mengkases data kas

- Mengakses data laporan warga

- Mengakses dat surat

- logout

2. Bendahara

- Login

- Mengelola data iuran warga

- Mengelola data kas RT-RW

- Mengkases data berita

- Mengakses data informasi

- logout

3. Lurah

- $\operatorname{login}$

- mengakses data berita

- mengkases data warga

- mengakses data laporan warga

- logout

\section{RT-RW}

- Login

- Mengelola data informasi

- Mengelola data iuran

- Mengelola data jenis surat

- Mengelola data kas

- Mengelola data laporan warga

- Mengelola daa pengajuan surat

- Mengelola data petugas

- Mengelola data warga

- logout

b) Kebutuhan sistem

- Pengguna diharuskan melakukan login terlebih dahulu dengan cara mengisi username dan password, apabila login berhasil maka setiap pengguna dapat mengkases sesuai akses yang ditentukan.

- Pengajuan data surat bisa dilakukan oleh pengguna warga dan pengajuan tersebut akan di verivikasi oleh bagian RT-RW.

- Proses pencarian bisa dilakukan berdasarkan filed yang ada.

- RT-RW dapat melakukan verifikasi pengajuan surat.

- Pengguna harus melakukan logiut ketika sudah selesai menggunakan aplikasi.

c) Usecase Diagram

Use case diagram atau diagram use case merupakan pemodelan untuk kelakukan (behavior) sistem informasi yang akan dibuat. Use case mendeskripsikan sebuah interaksi antara satu atau lebih aktor dengan sistem informasi yang akan dibuat[12].

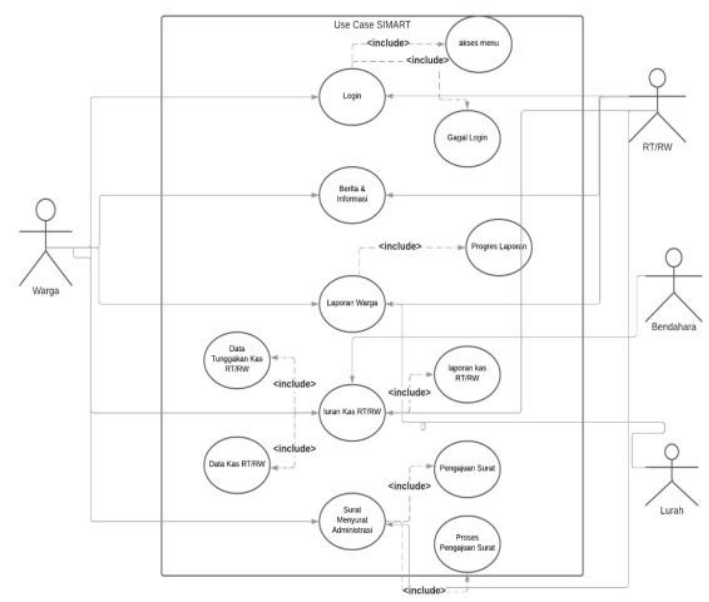

Gambar 1. Usecase diagram

Gambar 1 merupakan usecase diagram pada aplikasi SIMART, yang meunjukan kelakuan dari pelaku (Aktor).

d) Basis Data

Basis data adalah kumpulan data yang saling berhubungan secara logis dan didesain untuk mendapatkan data yang dibutuhkan oleh suatu organisasi[13]. Basis data aplikasi SIMART mengunakan MySQ1 dan di implementasi menggunakan LRS (Logical Record Structure). Mysql termasuk didalam kategori database management system, suatu 
basis data yang terstruktur dalam proses pengolahan dan penampilan datanya[14].

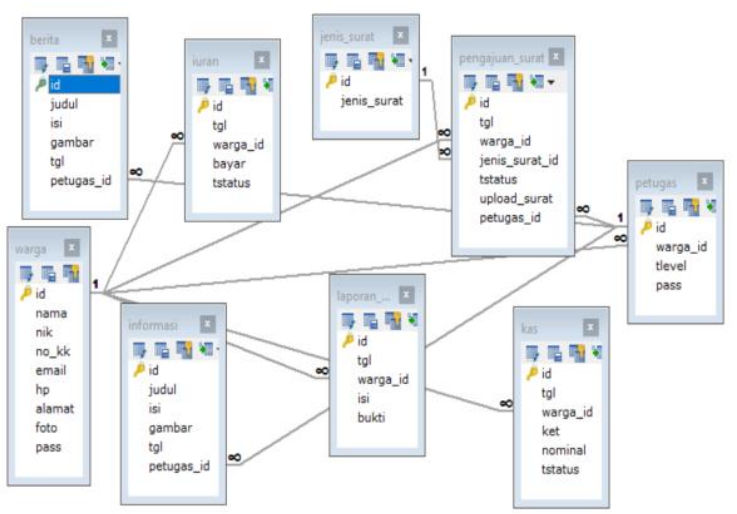

Gambar 2. Logical record structure

Gambar 2 merupakan LRS (Logical Record Structure) pada aplikasi SIMART. Logical record structure (LRS) merupakan hasil transformasi ERD ke LRS yang melalui proses kardinalitas dan menghasilkan atribut-atribut yang saling berelasi[15].

\section{HASIL DAN PEMBAHASAN}

Penelitian ini menghasilkan aplikasi yang bernama SIMART dan akan di terapkan pada objek penelitian khususnya di RT/RW. Aplikasi SIMART bisa digunakan oleh pengurus RT/RW dan warga dalam proses mencatat dan mengolah data-data seperti pengajuan surat dan laporan kas RT/RW. Selain itu juga aplikasi ini menghasilkan data informasi terkait kegiatan yang di lakukan di RT/RW misalnya kegiatan gotong royong dan lain sebagainya. Aplikasi SIMART juga memudahkan warga untuk membuat laporan kejadian mendadak di RTRW tersebut dengan cepat dan mudah. User interface

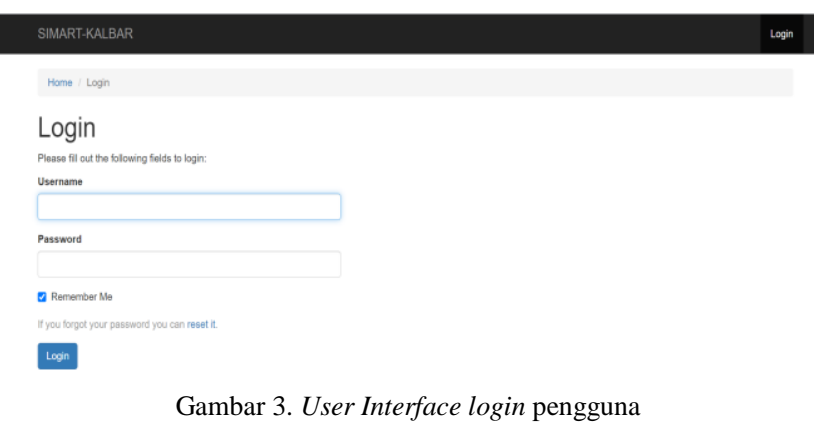

Untuk melakukan pengamanan data maka aplikasi ini dibuat dengan autentifikasi login menggunakan username dan password, sehingga tidak mudah diakses oleh pengguna yang berkepentingan.

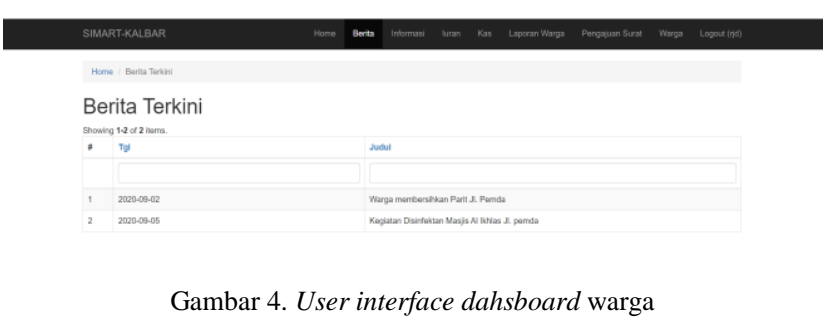

Pada dashboard warga terdapat informasi berupa berita-berita terkini yang dapat diakses agar warga tidak ketinggalan informasi atau berita.

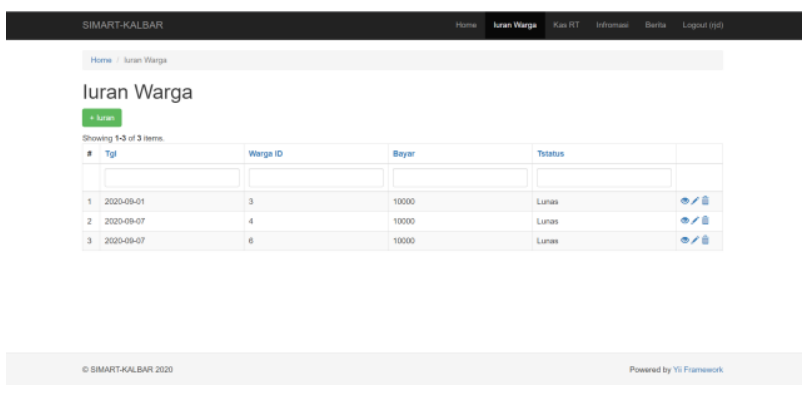

Gambar 5. User interface dahsboard bendahara

Tujuan adanya menu bendahara adalah untuk melakukan transaksi keuangan seperti melakukan penagihan iuaran kas RT/RW, mengelola laporan keuangan RT/RW dan menampilkan laporan penggunaan dana kas RT/RW.

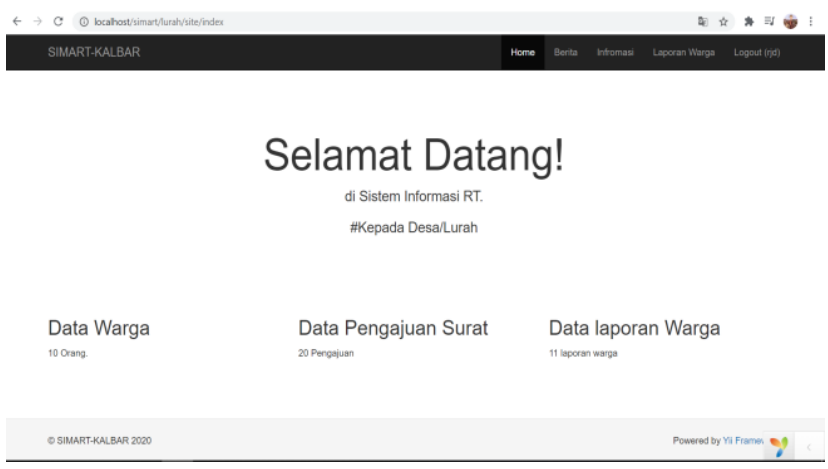

Gambar 6. User interface dahsboard lurah

Pengurus RT/RW adalah mereka yang dipilih masyarakat dan disahkan kelurahan dan kecamatan, sehingga lurah harus dapat melakukan monitoring kinerja RT/RW disekitar wilayahnya. 

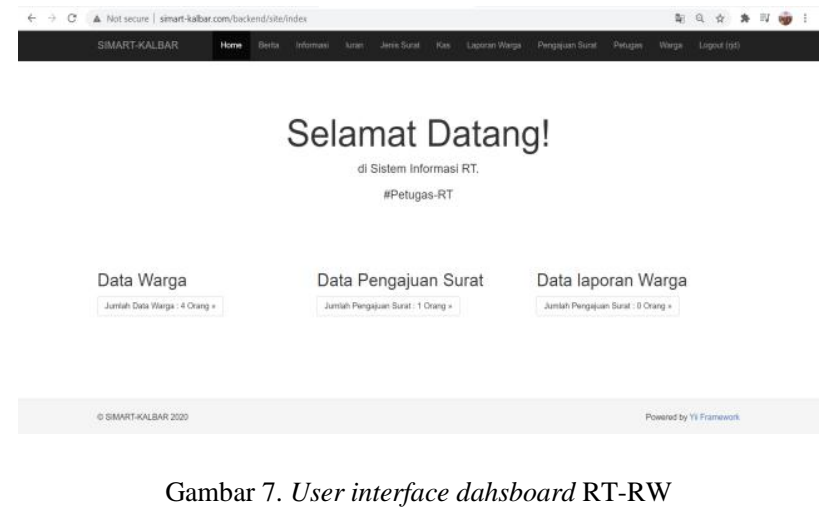

Pengurus RT/RW adalah mereka yang dipilih masyarakat dan disahkan kelurahan dan kecamatan, sehingga harus dapat menjalankan fungsi lain dari administratif dengan melakukan monitoring laporan warga RT/RW disekitar wilayahnya.

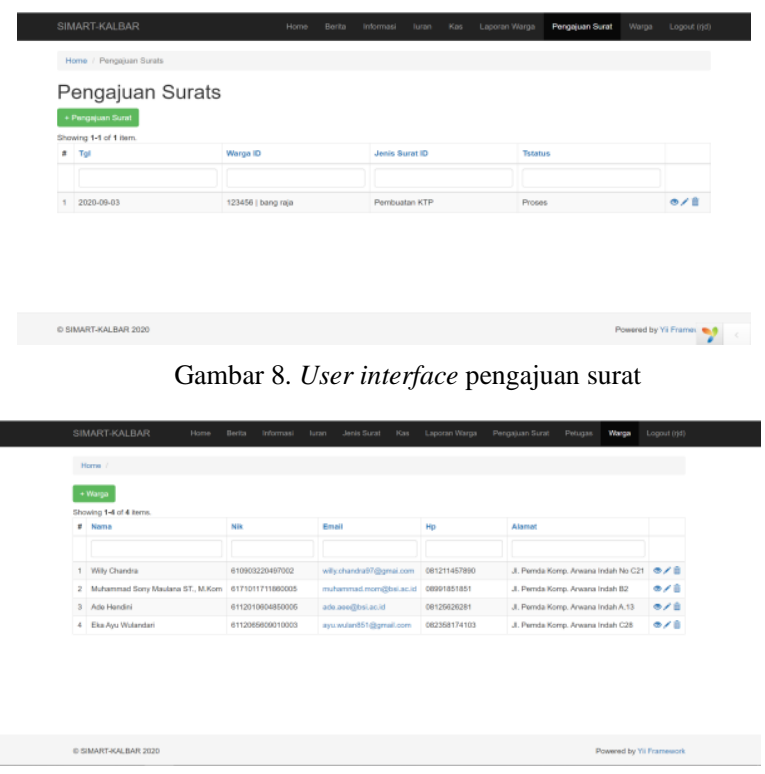

Gambar 9. User interface kas masuk \& keluar

1) Pembuatan Kode: Pembuatan kode program menggunakan framework yii2. Proses pembuatan juga sudah standar dengan konsep Object Oriented Programming yaitu memiliki Model View dan Controller. Sehingga pembuatan aplikasi SIMART tidak memakan waktu yang lama.

2) Pengujian: Pengujian yang dilakukan adalah dengan pengujian blackbox testing. Dimana setiap interface di uji satu persatu. Yaitu dimulai dari pengujian login, menu-menu yang ada di setiap aktor atau pengguna hingga logout.

3) Implementasi: Implementasi yang dilakukan pada penelitian ini yaitu dengan menghosting sehingga bisa langsung di terapkan. Domain yang sudah terdaftar yaitu simart-kalbar.com.

\section{KESIMPULAN}

Hasil penelitian menunjukkan bahwa aplikasi SIMART dapat diimplementasikan pada RT-RW untuk menggantikan pencatatan dan pengelolaan secara konvensional, terutama dalam proses pengajuan surat.

Aplikasi SIMART di gunakan oleh 4 aktor yaitu bagian warga, bagian bendahara, bagian lurah, dan bagian RT/RW. Setiap aktor memiliki hak akses tertentu dalam pengelolaan data yang ada.

\section{UCAPAN TERIMA KASIH}

Peneliti mengucapkan terima kasih dan penghargaan kepada Jurnal Sistem dan Teknologi Informasi Universitas Tanjungpura atas bantuannya dalam penerbitan artikel ilmiah saya yang berjudul "Rancang Bangun Dashboard Smart Sistem Manajemen RT/RW Untuk Mendukung Society $5.0 "$.

\section{DAFTAR PUSTAKA}

[1] M. Fukuyama, "Society 5.0: Aiming for a New Human-Centered Society”, Japan Spotlight, pp. 47-50, July-Agustus, 2018.

[2] T.W.W. Utomo dan B. M. Andalina, "Pengembangan Kapasitas Rukun Tetangga/Rukun Warga Sebagai Organisasi "Akar Rumput' Dalam Era Desentralisasi Luas", Jurnal Ilmu Administrasi, Vol 6(1), pp.18-33, 2009

[3] Sutarmidji. "Peraturan Daerah Kota Pontianak Nomor 10 Tahun 2011 Tentang Rukun Tetangga (RT) Dan Rukun Warga (RW)", Pontianak, Oktober, 2011.

[4] N. Purwatmini, Shalahudin dan H.S. Yudiarso, "Peran Ketua Rukun Warga Sebagai Servant Leader dan Masyarakat untuk Keberhasilan Mendapatkan Proyek Pembangunan Infrastruktur", Jurnal Ilmu Administrasi Publik UMA, Vol.8(1), pp. 50-56, 2020.

[5] M. Khafid dan A. Wahyudin, "Penyusunan Dan Implementasi Sistem Pelayanan Publik Surat Pengantar Rt/ Rw Online Untuk Mewujudkan Semarang "Smart City", Jurnal Rekayasa, Vol.16(20), pp.209-218, 2018.

[6] Humas, "Presiden: Prioritas Kita Cegah Penyebaran Covid-19 Lebih Luas Lagi", https://setkab.go.id/presiden-prioritas-kitacegah-penyebaran-covid-19-lebih-luas-lagi/

[7] Sarmidi, E.D.S. Mulyani, R.A. Wiyono dan Gunawan, "Sistem Informasi Warga (Simwarga) Tingkat RT/RW Berbasis Web", Seminar Nasional Pengabdian pada Masyarakat(SNPMas), pp. 447-454, 2019..

[8] R. A. Sukamto dan M. Shalahuddin, "Rekayasa Perangkat Lunak terstruktur dan berorentasi objek", Informatika Bandung:2015.

[9] Mulyani, Sri. 2016. Metode Analisis dan Perancangan Sistem. Bandung: Abdi SisteMatika.

[10] Panduan Definitif Untuk Yii 2.0 https://www.yiiframework.com/doc/guide/2.0/id/intro-yii

[11] U. Hanifah, R. Alit dan Sugiarto, "Penggunaan Metode Black Box Pada Pengujian Sistem Informasi Surat Keluar Masuk", Jurnal SCAN, Vol XI (2), pp.33-40, 2016.

[12] Pragestu, Steven, Sujaini Herry, dan Negara, A. B. P Implementasi Augmented Reality dengan Memanfaatkan GPS Based Tracking pada Sistem Pengenalan Gedung Universitas Tanjungpura. Jurnal Edukasi dan Penelitian Informatika (JEPIN), Vol. 1, No. 2, pp. 122-127, 2015.

[13] Indrajani, "Database Design (Case Study All in One)", PT Elex Media Komputindo, Jakarta, 2015.

[14] M.Q. Khairuzzaman, "Analisis Dan Perancangan Sistem Informasi Electronic Customer Relationship Management(e-Crm) PT. Delta Jaya Motor Singkawang", Jurnal Khatulistiwa Informatika 4(1), 1-224.

[15] A. Lubis,"Basis Data Dasar Untuk Mahasiswa Ilmu Komputer", CV. Budi Utama,2016. 